\title{
Content Analysis of Indonesian National Security Architecture
}

\author{
Surwandono \\ International Relations \\ Universitas Muhammadiyah Yogyakarta \\ Yogyakarta, Indonesia \\ wsurwandono@yahoo.com
}

\author{
Masyithoh Annisa Ramadhani \\ International Relations \\ Universitas Muhammadiyah Yogyakarta \\ Yogyakarta, Indonesia \\ ramadhannisa91@gmail.com
}

\begin{abstract}
This paper aims to explain the relationship between the traditional and non-traditional security threats that Indonesia is facing, and the policy options undertaken by Indonesia to address them. Given the growing concern about the existing security threats, it is important to evaluate the national security architectures. This article applies content analysis techniques to understand the policy construction chosen by Indonesian government through a series of regulations; the State Intelligence Law, the Social Conflict Management Law, the AntiTerrorism Law, and National Security Bill. The research finds that Indonesian national security architectures emphasizes on the military-based approach, rather than the civil-based approach.
\end{abstract}

Keywords : content analysis, security threats, national security architectures, Indonesia

\section{INTRODUCTION}

Given the changing global orders involving both state and non-state actors' involvement, the security challenges that countries are facing would be more multidimensional since it is not only the military threat, but also the broader type and form of threats involving more actors. Indonesia's strategic environment as a country with the extensive diversity is likely to pose both challenges and opportunities as to how the national security architectures will be constructed.

As we look at the current Indonesian national security architectures, a disconnect is apparent between the nature of a growing number of the non-traditional security threats - for example social conflict and terrorism, and the rickety regulations which too often emphasize the military-based approach instead of the civil-based approach. It is therefore important to evaluate the national security architectures by doing a content analysis so that we could examine on how military and civil society contribute to the national security architectures.

Based on the proposition that the civil-based approach is less prioritized rather than the military-based approach in addressing the security threats, this article will discuss a series of regulations on Indonesian national security comprising the State Intelligence Law, the Social Conflict Management Law, the Anti-Terrorism Law, and the proposed National Security Bill. Further, some indicators would be analyzed in order to understand the extent to which military-based approach is used to establish the robust national security architectures in Indonesia; and therefore filling the remaining gap on how civil-based approach should be taken into account. These indicators are (1) the principle of the regulations and on how they interlink in achieving the objectives to establish a robust national security architectures, (2) the main actor addressing the security threats, and (3) the strategy to pursue the objectives stated in the regulations.

This article is divided into four sections. Section one includes this introduction. The second section examines the direction in which Indonesian national security architectures is constructed. The third section describes some examples of critical security threats in Indonesia, with special emphasis on social conflict and terrorism. The fourth section examines the findings and discussions emphasizing on the indicators analysed. Finally, the paper will close with a conclusion that summarizes Indonesia's preference to consider military-based approach rather than civil-based approach as the main option in the construction of Indonesian national security architectures.

\section{DISCUSSION}

As stated out in the 1945 Constitution of the Republic of Indonesia article 30, Indonesia believes in the People's Defense and Security System (Sistem Pertahanan dan Keamanan Rakyat Semesta - Sishankamrata) in which every citizen shall have the right and duty to participate in the defense and security of the state [1]. However, the primacy of military and police as the main components to safeguard the nation is inevitable as the country is undergoing a security sector reform since the fall of Suharto. Even though civilian political forces are now free from military influence and interventions, and indeed are in a better political position, their contribution is still constrained by formidable problems at strategic, policy, and technical levels in exercising their authority over the military [2].

It is therefore important to encourage the involvement of civil society, for instance through the CSO (Civil Society 
Organizations), in the formulation of various security policies. A research conducted by Institute for Defense, Security, and Peace Studies (IDSPS) Jakarta in 2007 found that CSO's role in affecting the legislation and policy in defense sector hasn't been as strong and effective as what we imagine all along because CSOs are still considered by the parliament "as cheerleaders" in the hurly-burly of legislation and policy formulation procedure [3].

In recent years, as the security threats have evolved from only the traditional security into the non-traditional security, it is critical to make an effort in order to avoid the high escalation of threats. The distinction of roles in each security actors implies to the contribution they could make in the construction of Indonesian national security architectures. To date, article 30 of the 1945 Constitution of the Republic of Indonesia stipulates the basic idea on the execution of state defence and security which will be through the people's defence and security system in the Indonesian Armed Forces and the Indonesian Police.

They will, therefore, become the main components in state defense system and supported by the reserved components and the support components whish consist of the citizens, natural resources, artificial resources, and national facilities which are prepared to support other components [4]. Nevertheless, authors believe that by separating the actors into these aforementioned components, it will potentially leave a sort of gap in the duties performed. If all security actors work hand in hand with the equal distribution of duties, the civil society could have a wider space to articulate their contributions in creating a robust national security architectures.

Despite the fact that Indonesia has been going a long way toward implementing a national vision of "Bhinneka Tunggal Ika" or unity in diversity, there remains a number of challenges pertaining to the security stability of the nation. Post-Soeharto era has witnessed an enormous security challenges as the country is undergoing a reformation, and folllowed by the decentralisation. One of the prolonged issues is in Papua in which it is argued that the driving factor behind the conflict is not ethnicity itself but rather government programs that lead to reinforcing - rather than crosscutting political, economic, and social cleavages along ethnic line [5]. In addition, the military-based approach conducted by the central government has hindered the peace resolution since it has led into more grievances of the people. Furthermore, the separatist movement in Maluku, followed by a number of conflict between religious groups, also constitutes as one of the prolonging conflicts that Indonesia experienced. A research conducted by Betts [6] found that the conflict development in Maluku is closely linked to the role of military in the province in where 17,000 troops are stationed and benefit from this situation given the willingness of the top military hierarchy who wanted to maintain the territorial system of the military. The government decision to drop more troops at that time could not prevent the conflict to end, instead, it has promoted the segregation in the society given their different ethnics, religion, and races. Thus, addressing the root causes; political, social, economic grievances should be prioritized at the first place.

Post 9/11, all countries in the world are dealing with the emergence of non-state actor such as those terrorists whose goals are threatening the society and creating public fear. Terrorism, according to Hoffman [7], is ineluctably about power: the pursuit of power, the acquisition of power, and the use of power to achieve political change through violence and coercive intimidation. Indonesia, a country with more than 200 million Muslim inhabitants has been one of the targets of transnational terrorism movements such as those of Al-Qaeda, Jemaah Islamiyah, Islamic States, and many others. Given the global patterns of terrorism, it is therefore important for Indonesia to address this through calling for the involvement of all instruments of national power. One of the most critical issues pertaining to Indonesia's counter-terrorism policy is on the role of Detachment 88 who has been criticized as too trigger-happy, resulting in the unnecessary deaths of terrorism suspects, and even torturing the terrorists suspects before the judicial process. However, there is an argument that the terrorism threat will likely never be completely eliminated in a country where a small but determined minority believes the state should be governed under Shariah Law, and indiscriminate violence is an acceptable means to achieve that goal [8].

In order to reveal the extent to which military-based approach is more dominant rather than civil-based approach in Indonesian national security architectures as written in the aforementioned laws, some significant phrases will be taken into account. First, it is a phrase on the principle of the regulations and on how they interlink in achieving the objectives to establish a robust national security architectures. Second, it is a phrase of main actor addressing the security threats, and third, it is a phrase of the strategy to pursue the objectives stated in the regulations.

\section{The Assessement of Pre-Threats and Post-Threats based on the Principle of the Regulations}

In order to better address the security threats, it is critical to make a considerable assessment, at least on the two following phases; first, the pre-threats, and second, the post-threats. The first idea on pre-threats assessment will require the job of intelligent on performing its duties to make an assessment about the likelihood of such security threats. Then, these reports would become the foundation of assessment for the 
following procedures to address the potential threats through the post-threats assessment conducted by the security actors.

The concept of "pre-emptive", reflecting the pre-attack assessment, is continuously promulgated by Bush administration after the 9/11 attack has been the inspiration for the state intelligent worldwide. With the broad definition, not only in terms of strike, pre-emptive effort emphasizes on the importance of information sharing and analysis through intelligence which further becomes the core component of national security architectures [9]. In Indonesia, after the enactment of the Law number 17 of 2011 on the State Intelligence, there has been a growing debate on the principle of the regulations. The law believes that the ethics of intelligent should comply with the national law. While at the same time the principles of rights, ethic code, and safety constitute as the basic approach in conducting the duties. With regard to the issue of rights, the notion of public freedom to access the public information is therefore questionned. Article 1 Law number 17 of 2011 on the State Intelligence stated that:

"Intelligence secret is an information, object, personnel, and/or an effort, job, intelligent activity which are protected and unaccessible, unknown, and cannot be owned by the unauthoritative."

In furtherance, it is stated in the article 25 that intelligence secret is state secret which therefore implies to the consequence that everyone or legal body is not allowed to open the intelligence secret. As the country believes in the idea of democracy in which the demand of transparency in governance sector is really high, it is critical to take society into account in the supervision of the regulations. Article 26 and 27 reiterates that Intelligence National Agency (Badan Intelijen Negara or BIN) should submit to the president. While the words bureaucracy in the regulations define the three actors in the intelligence activity; police $(46,1 \%)$, military $(30,7 \%)$, and judicial body $(23,07 \%)$. This reflects to the centrality of executive power which potentially undermines the right of civil society in which intelligence activities should be held accountable.

With regard to the social conflict in Indonesia, the Law number 7 of 2012 on the Social Conflict Management believes that the sources of conflict in Indonesia vary from politics, economic, socio-cultural, inter-religious believers, races, ethnicity, border disagreement, and unbalance distribution of natural resources in society. In the case of Maluku, the role of security forces in provoking the conflict is indicated by the arms distribution in the society, the biased attitude of state officers in handling and preventing the unrest, the involvement of state apparatus in numerous act of violence, and the use of religious symbols by some security forces [10].
Social participation and local wisdom are therefore important to be taken into account in managing the conflict given the phrases mentioned in the law about the role of custom structure (pranata adat) which is $10,74 \%$ and social structure (pranata sosial) which is $11,57 \%$ in supporting the regional and central government to address the threats. However, their participations are sometimes limited given the control of local government which accounts $28,92 \%$ during the conflict management phase comprising conflict avoidance conflict stopping, and post-conflict recovery.

\section{Searching for A Common Ground among Security Actors}

Given the variety of roles played by the security actors in the construction of Indonesian national security architectures, it is therefore important to find the common ground among them in order to avoid the possibility of overlapping. In light of this, constructivist shares the idea that security is a site of negotiation (between political leaders and domestic audiences in particular) and contestation (between different actors elaborating different visions of 'our' values and how 'we' should act) [11]. Thus, the role of government is prominent in framing the extent to which some issues could be considered as the security threats and therefore implying upon the policy to undertake. To this end, the State Intelligence Law, the Social Conflict Management Law, the Anti-Terrorism Law, and National Security Bill clearly mentioned the centrality of president to manage the national security architectures. Despite the fact that president is supported by some security actors such as Coordinating Ministry of Political, Legal, and Security Affairs, Indonesian Armed Forces, Indonesian Police, an "Ad-Hoc" body, and the special council.

According to the article 42 Law number 7 of 2012 on the Social Conflict Management, the "Satuan Tugas Penyelesaian Konflik Sosial" will work on the basis of "ad-hoc" system. It means, once the conflict is likely to end, the committee will end their missions. While in fact, social problem cannot be solved at this short period of time. Therefore, it is critical to find the much robust security architecture, with more involvement from the civil society, but by no means to limit the presence of military and police.

The current Indonesia's national security architecture relies on a series of separated regulations designed to address all various kinds of security threats. Despite the centrality of President as the highest authority to manage the national security system, the extent to which the other elements such as Indonesian Armed Forces, Indonesian Police, and civil society cooperate remains unclear. As threats have evolved from the traditional security involving military and other tangible threats into the non-traditional security involving more nonstate actors, thus it is important for the government to invite civil society to take part into the national security 
architectures. However, as the National Security Bill is still under discussion in the House of Representative, there remains a sort of public rejection given the potential of human rights violation. Article 20 stipulates the element of national security will be arranged into a decentralized order from national, province, and district government; while civil society is put in the last order [12]. This will leave a biased interpretation as it gives more authority to regional government to act on behalf of their favor to suppress the civil society groups which may be in a different side with them.

Furthermore, the role of Indonesian Armed Forces will also be mixed with the Police while in fact their roles have clearly been explained in Article 30 of 1945 Constitution on the state defense and national security which stipulates that any efforts for the state defense and security are executed through the people's defense and security system by the Indonesian Armed Forces and the Indonesian Police. Thus, the major steps that need to be taken is the comprehensive review of the policy, strategy and structure of the TNI and the completion of a legislative agenda that would regulate the employment of the TNI in assisting the police and civil community [13]. On the other hand, Those who support the enactment of this Bill believes that this will be a guideline to realize adjustment, relation, and synchronization of the implementation of legislation related to national security and to complete what has not been contained in the existing legislation [14].

One of the most striking features of the Bill introduces National Security Council (NSC) as the only one advisor for President as to how national security system is established. As stipulated in article 24 of the Bill, NSC holds a very crucial responsibility in Indonesian national security architectures. As such, NSC will have to formulate national security policies and strategies; assess the progress of potential and actual threats along with the threats escalation, determine the main and supporting element of national security, control the organizing of national security, examine and assess the risk of policy and strategy applied, and also examine and assess the capability of the resources in organizing national security [15].

Given the existence of some other bodies which too often have the overlapping jobs such as National Resilience Council (Wantanas) and National Resilience Institute (Lemhanas), the extent to which NSC is critically needed remains unclear. Inventing new body will surely need a new budget allocation. Thus, maximizing the role of existing institutions and making a clear distinction on their jobs would be more reasonable. Hence, authors believe that searching for a common ground among security actors will shape the direction of Indonesian national security architecture so that civil society's contributions could be accomodated.

\section{State Responsibility vis-a-vis Human Rights Values}

After the country was shocked by the Bali bombing in 2002, President Megawati issued the Interim Law no 1 of 2002 on the Eradication of the Crime of Terrorism. Later, the enactment of Anti-Terrorism Law no 15 of 2003 strengthens government's commitment in providing the legal framework for terrorism eradication. This later becomes the core for other supporting legal frameworks for instance President Instruction no 4 of 2002 on the establishment of DKPT (Desk Koordinasi Pemberantasan Terorisme) which later has transformed into Detachment 88, Acts no 34 of 2004 on Indonesian Army's role in state of terror, Government Regulation no 46 of 2010 on the establishment of BNPT, and Acts no 9 of 2013 about terrorism funding.

However, some terms such as "widespread atmosphere of terror/fear" and "mass casualties" are not clearly elucidated, so that it potentially leaves a gap for any subjective interpretation based of each security actor. Further, some have wondered if this may bring a chance for political oppression by the authority given the legality of conducting some assessments.

The law, however, mostly focuses on the post-threats assessment and said less about the pre-threats assessment. According to article number 45 of 2003 Anti Terrorism Law, President holds the highest authority as to how counterterrorism policy in Indonesia is carried out and to formulate the policy and operational actions. However, there has been going a public debate on strengthening the capacity of the law given its weak construction on the pre-threats assessment. To this end, Ansyaad Mbai, the former Head of the National Counterterrorism Agency (BNPT) believes that a number of convicted Indonesian terrorists are returning to violent jihad after being released from prison, highlighting a need for more proactive measure along with tougher laws [16]. On the other hand, another issues is in article 25 (2) providing the legal authority to investigate the suspects for a maximum period of six months for the purpose of investigation and prosecution. However, the bills proposed currently seeks to revise this by adding more time for an extension so that the investigators may conduct more robust approach to the suspected terrorists. This has raised a growing concern from the human right activist since it may bring a wider chance for further investigation without any guarantee the extent to which its transparency could be ensured.

According to President Regulation (Perpres) number 46, 2010, BNPT serves as the center for crisis control when there is an act of terror, who also becomes the facility for the president to decide the upcoming policy and to maximize the resources to overcome the terror. However, given the rising concern of the returning fighters from Syria to Indonesia, it is therefore critical for Indonesia to reformulate its national 
security construction with regard to anti-terrorism. The national discourse to revise has gained a prominence support from some nation elements such as stated by former Coordinating Minister for Political, Legal, and Security Affairs Luhut Pandjaitan [17].

With regard to the deradicalization process involving the civil-society power, Muhammadiyah, one of largest Islamic organizations in Indonesia, has tried to advocate Siyono, who has been killed by Detachment 88 on April 2016 [18]. It is further emphasized by Dr Haedar Nashir - the head of Muhammadiyah - that Muhammadiyah aims to give the moral support and advocacy to Siyono's family as part of their commitment to promote the importance of safeguarding the basic human rights in Indonesia and emphasizing the need of the law accountability in the operation [19]. While the police rejects the autopsy conducted by both Komnas HAM \& Muhammadiyah by believing that they will only believe on the analysis from police doctor. It shows how civil society's role is undermined [20]. This pattern should therefore be duplicated by the other civil society group so that the policy outcomes of Indonesian national security would put society as not only the object, but also the subject whose contributions matter.

\section{CONCLUSION}

Given the changing global order in the foreseeable future, Indonesia will potentially deal with a number of security challenges which require a robust policy construction as to how the threats could be addressed. The current juncture of Indonesian national security architectures do not articulate explicitly the concept of security threats which thereore implies upon the subjective interpretations of the authoritative institutions. The lack of one integrated regulation to manage the synergy and roles distribution is believed to be one of the hindrance to the clear direction of the national security architectures in Indonesia. A coherent strategic network is needed, by not only applying the tactical and temporary strategy but a strategic approach through the involvement of civil society. In addition, having analysed the existing regulations; the State Intelligence Law, the Social Conflict Management Law, the Anti-Terrorism Law, and National Security Bill; it is found that the strategies pursued emphasize on the post-threats assessment rather than the pre-threats assessment.

Thus, in order to establish a robust national security architectures which promotes the idea of inclusivity, searching for a common ground on defining the security threats and also measuring the extent to which all national elements could contribute is recommended. As such, the government should accomodate the aspirations of people or other civil society groups and take them into account into the formulation of regulation.

\section{REFERENCES}

[1] Indonesia, R. o. (1945). Retrieved from Undang-undang Dasar Negara Republik Indonesia tahun 1945:

http://www.biomaterial.lipi.go.id/main/wpcontent/uploads/2013/03/UUD-1945-amandemen-terbaru.pdf

[2] Sukma, R. (2003). Security Sector Reform in Indonesia: the Military and the Police. Netherlands Institute of International Relations 'Clingendael'

[3] Makaarim, M. (2007, November). Indonesian Civil Society Organizations Strategies Maps in Security Sector Reform Advocacy : A General Overview. (M. Makaarim, Performer) Jakarta, Indonesia.

[4] Indonesia, D. M. (2015). Defence White Paper. Jakarta : Defence Ministry of the Republic of Indonesia.

[5] Walsh, E. (2012). Peace and Stability in Papua Reuires a Comprehensive Policy Approach . Strategic Review , 69.

[6] Betts, I. L. (2004). Post-Suharto Social Conflict in Indonesia: Analysis and Treatment . ICG.

[7] Hoffman, B. (2008). Inside Terrorism . Retrieved from NY Times: https://www.nytimes.com/books/first/h/hoffman-terrorism.html

[8] Indonesia, R. o. (2011). Undang-Undang Republik Indonesia nomor 17 tahun 2011 tentang Intelijen Negara

[9] Bunn, M. E. (2003, July). Preemptive Action: When, How, and to What Effect? Retrieved from Strategic Forum http://www.comw.org/qdr/fulltext/0307bunn.pdf

[10] Ikrar Nusa Bhakti, e. a. (2009). Military Politics, Ethnicity, and Conflict in Indonesia. Oxford: CRISE Center for Research on Inequality, Human Security, and Ethnicity.

[11] McDonald, M. (2011). Constuctivism . In P. D. Williams, Security Studies : An Introduction (p. 65). London : Routledge.

[12] Indonesia. (2012). Rancangan Undang-undang Republik Indonesia tentang Keamanan Nasional .

[13] Lowry, B. (2016). The Puzzle of Security Sector Reform in Indonesia Retrieved October 13, 2016, from The Strategist: http://www.aspistrategist.org.au/puzzle-security-sector-reformindonesia/

[14] Nakir, B. G. (2015). The Need of the Law on National Security. In WiRA (p. 14). Jakarta: Ministry of Defense Republic of Indonesia. Retrieved from Kementerian Pertahanan .

[15] Indonesia. (2012). Rancangan Undang-undang Republik Indonesia tentang Keamanan Nasional .

[16] Elliott, T. (2014). President Yudhoyono's Solid Record Fighting Terrorism . Strategic Review , 48.

[17] The Jakarta Post. (2016, July 20). Govt Backs TNI's Role in Anti-Terror Law. Retrieved October 08, 2016, from The Jakarta Post: http://www.thejakartapost.com/news/2016/07/20/govt-backs-tnis-rolein-anti-terror-law.html

[18] Kompas. (2016). Advokasi Keluarga Siyono, Cara Deradikalisasi ala Muhammadiyah. Retrieved from KOMPAS http://nasional.kompas.com/read/2016/04/29/22170061/Advokasi.Keluar ga.Siyono.Cara.Deradikalisasi.ala.Muhammadiyah

[19] CNN. (2016). Muhammadiyah Beri Bantuan Moral dan Advokasi Keluarga Siyono. Retrieved from CNN Indonesia: http://www.cnnindonesia.com/nasional/20160401183700-12121079/muhammadiyah-beri-bantuan-moral-dan-advokasi-keluargasiyono/

[20] Indonesia, B. (2016). Polisi Tolak Hasil Autopsi Siyono versi Komnas dan Muhammadiyah. Retrieved from BBC Indonesia: http://www.bbc.com/indonesia/berita indonesia/2016/04/160411 indon $\underline{\text { esia_polisi_siyono }}$ 